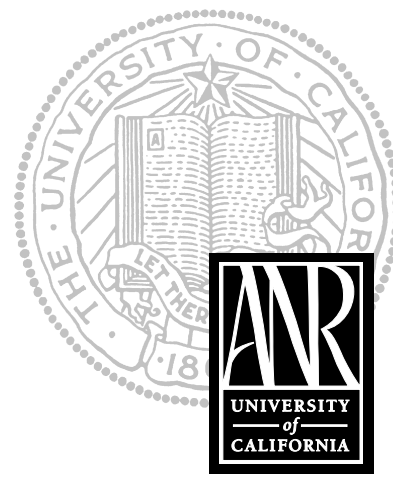

UNIVERSITY OF CALIFORNIA

Agriculture

and Natural Resources

http://anrcatalog.ucdavis.edu

\title{
Alternaria Diseases
}

FRANKLIN LAEMMLEN, University of California Cooperative Extension Farm Advisor, Santa Barbara and San Luis Obispo Counties

Diseases caused by Alternaria species are very common and are worldwide in their occurrence. Important host plants include a variety of crops such as apples, broccoli, cauliflower, carrots, potatoes, Chinese cabbage, tomatoes, bok choy, and citrus, plus many plants used as ornamentals and a number of weeds.

\section{S Y M P T O M S}

Alternaria generally attacks the aerial parts of its host. In the leafy vegetables, symptoms of Alternaria infection typically start as a small, circular, dark spot. As the disease progresses, the circular spots may grow to $1 / 2$ inch $(1 \mathrm{~cm})$ or more in diameter and are usually gray, gray-tan, or near black in color.

Due to fluctuating environmental conditions, the pathogen does not have a uniform growth rate, thus spots develop in a target pattern of concentric rings (fig. 1). Where host leaves are large enough to allow unrestricted symptom development, the target spots are diagnostic for Alternaria as there are few other pathogens that cause this type of diagnostic expression. Apart from the target pattern, the lesion is also often covered with a fine, black, fuzzy growth. This growth is the Alternaria fungus sporulating on the dying host tissues.

Many Alternaria species also produce toxins that diffuse into host tissues ahead of the fungus. Therefore, it is not uncommon to see a yellow halo that fades into the healthy host tissues that surround the target spot.

Dark, sunken lesions are usually the expression of Alternaria infections on roots, tubers, stems, and fruits. The fungus may sporulate in these cankers, causing a fine, black, velvety growth of fungus and spores to cover the affected area.
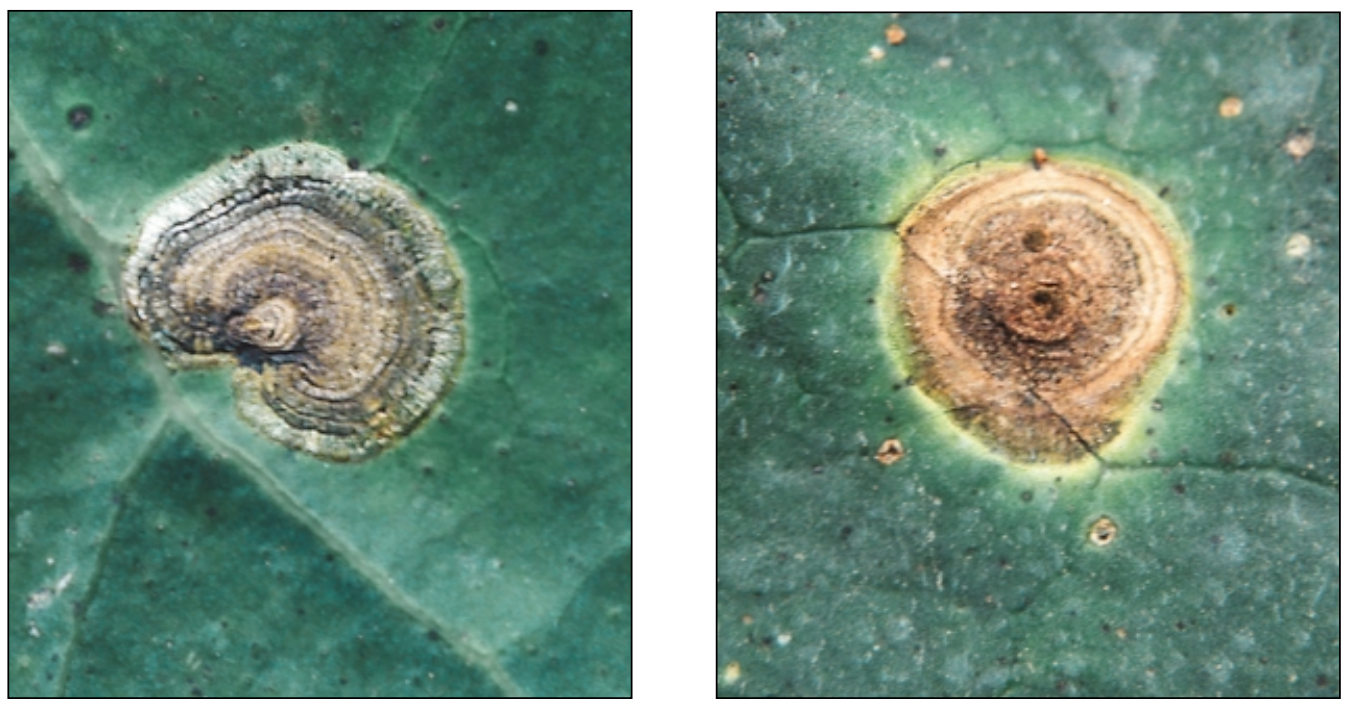

Figure 1. Leafspot of crucifers caused by Alternaria brassicae, showing the typical target spot composed of concentric rings. 


\section{THE PATHOGEN}

The spores of Alternaria species are often beaked and always multicelled. The cells are divided longitudinally and transversely. Spores are dark and borne singly or in chains (fig. 2). Some Alternaria species and the diseases they cause on specific hosts include

- Alternaria dauci (carrot leafblight)

- A. radicina (black rot of carrot)

- A. brassicae and A. brassicicola (leaf spot of crucifers)

- A. solani (tomato early blight and fruit rot)

- A. brassicae or A. brassicicola (broccoli headrot)

- A. tenuis and A. alternata (fruit spot on peppers)

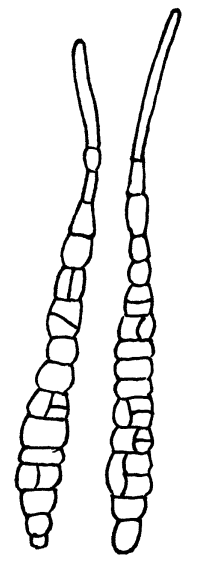

A

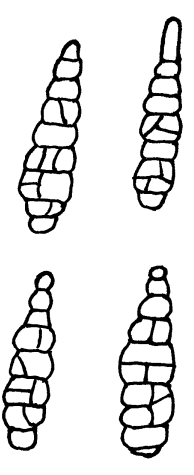

B

Figure 2. Conidia of Alternaria brassicae (A) and Alternaria brassicicola (B).

\section{B IOLOG Y}

Plant pathogenic Alternaria species survive between crops as spores and mycelium in infected plant residues or in and on seeds. If the fungus is seedborne, it may attack seedlings, causing damping-off, stem lesions, or collar rot. Most often, however, the fungus grows and sporulates on plant residues during periods of rain, heavy dew, or under conditions of good soil moisture. Spores are wind blown or splashed onto plant surfaces where infection occurs. The spores must have free moisture to germinate and infect. Penetration of the host can be direct, through wounds, or through stomata (fig. 3). Tissues that are stressed, weak, old, or wounded are more susceptible to invasion than sound, vigorous tissues. 


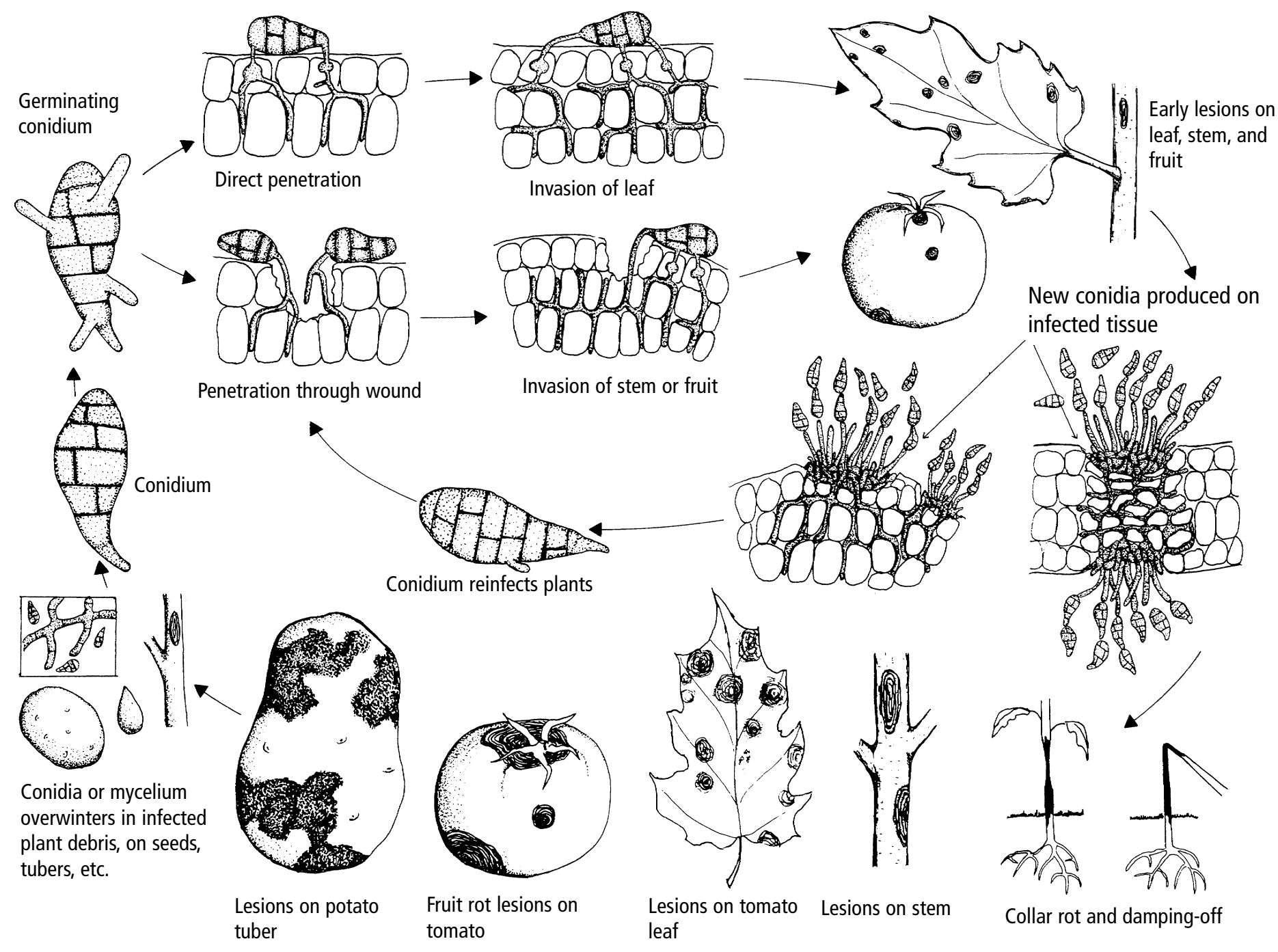

Figure 3. Development and symptoms of diseases caused by Alternaria.

(Source: Agrios, G. N. 1997. Plant pathology, 4th edition. San Diego: Academic Press.)

\section{DISEASE MANAGEMENT}

Suppression of Alternaria diseases can be accomplished in several ways. Some plant cultivars carry resistance. When seed may be carrying the fungal spores, using diseasefree seed or seed that has been treated can greatly reduce disease incidence. Rotating crops so that susceptible crops follow non-host crops is useful in reducing disease incidence. Crop residue destruction and weed control also helps reduce disease.

Ultraviolet light has been shown to be essential for spore formation in Alternaria species. Therefore, under greenhouse growing conditions, the use of ultraviolet light-absorbing film can greatly reduce the incidence of some Alternaria diseases.

Finally, there are a number of fungicides that have activity against Alternaria fungi. Chlorothalonil, captan, fludioxonil, imazalil, iprodione, maneb, mancozeb, thiram, and selected copper fungicides have varying degrees of efficacy against Alternaria species. Consult the product label for registered uses and dosage recommendations. 


\section{FOR MORE INFORMATION}

You'll find detailed information on many aspects of disease and pest management in these titles and in other publications, slide sets, and videos from UC ANR:

Alive and Well: Sustainable Soil Management, Video V92-D

Natural Enemies Handbook: The Illustrated Guide to Biological Pest Control, Publication 3386

Pests of the Garden and Small Farm: A Grower's Guide to Using Less Pesticide, Second Edition, Publication 3332

Plants in California Susceptible to Phytophthora cinnamomi, Publication 21178

Visit our online catalog at http://anrcatalog.ucdavis.edu. You can also place orders by mail, phone, or fax, or request a printed catalog of publications, slide sets, and videos from

University of California

Agriculture and Natural Resources

Communication Services

6701 San Pablo Avenue, 2nd Floor

Oakland, CA 94608-1239

Telephone: (800) 994-8849 or (510) 642-2431

FAX: (510) 643-5470

E-mail inquiries: danrcs@ucdavis.edu 
An electronic version of this publication is available on the ANR Communication Services website at http://anrcatalog.ucdavis.edu.

\section{Publication 8040}

(C)2001 by the Regents of the University of California, Division of Agriculture and Natural Resources. All rights reserved.

The University of California prohibits discrimination against or harassment of any person employed by or seeking employment with the University on the basis of race, color, national origin, religion, sex, physical or mental disability, medical condition (cancer-related or genetic characteristics), ancestry, marital status, age, sexual orientation, citizenship, or status as a covered veteran (special disabled veteran, Vietnam-era veteran or any other veteran who served on active duty during a war or in a campaign or expedition for which a campaign badge has been authorized). University Policy is intended to be consistent with the provisions of applicable State and Federal laws.

Inquiries regarding the University's nondiscrimination policies may be directed to the Affirmative Action/Staff Personnel Services Director, University of California, Agriculture and Natural Resources, 300 Lakeside Drive, 6th floor, Oakland, CA 94612-3550; (510) 987-0096. For a free catalog of other publications, telephone (800) 994-8849. For help downloading this publication, call (530) 754-5112.

To simplify information, trade names of products have been used. No endorsement of named or illustrated products is intended, nor is criticism implied of similar products that are not mentioned or illustrated.

\section{Warning on the Use of Chemicals}

Pesticides are poisonous. Always read and carefully follow all precautions and safety recommendations given on the container label. Store all chemicals in the original labeled containers in a locked cabinet or shed, away from food or feeds, and out of the reach of children, unauthorized persons, pets, and livestock. Confine chemicals to the property being treated. Avoid drift onto neighboring properties, especially gardens containing fruits or vegetables ready to be picked. Do not place containers containing pesticide in the trash nor pour pesticides down sink or toilet. Either use the pesticide according to the label or take unwanted pesticides to a Household Hazardous Waste Collection site. Contact your county agricultural commissioner for additional information on safe container disposal and for the location of the Hazardous Waste Collection site nearest you. Dispose of empty containers by following label directions. Never reuse or burn the containers or dispose of them in such a manner that they may contaminate water supplies or natural waterways.

pr-12/01-GM/VFG

ISBN 978-1-60107-218-4

This publication has been anonymously peer reviewed for technical accuracy by University of California scientists and other qualified professionals. This review process was managed by the ANR Associate Editor for Vegetable Crops. 